Penelitian ...

\title{
PENGEMBANGAN KETERAMPILAN MEMBANTU DIRI SENDIRI PADA ANAK PANTI ASUHAN USIA 4-5 TAHUN
}

\author{
Ade Dwi Utami \& Ristiaji Yunitami \\ e-mail: ade.dwi.utami@gmail.com \\ PG PAUD Universitas Negeri Jakarta
}

\begin{abstract}
Abstrak: Penelitian ini bertujuan untuk meneliti kasus mengenai keterampilan membantu diri sendiri (selfhelp skill) pada anak panti asuhan. Penelitian ini berlangsung di Yayasan Arrohmaniyah Panti Asuhan Yatim Piatu Anni'mah, Cakung, Jakarta Timur. Metode yang digunakan dalam penelitian ini adalah studi kasus. Teknik pengumpulan data yang digunakan yaitu observasi, wawancara, dan dokumentasi. Dalam analisis data, penelitian ini menggunakan teknik Miles and Huberman. Aktivitas yang dilakukan dalam analisis data antara lain reduksi data, penyajian data, dan penarikan kesimpulan/verifikasi. Anak-anak panti asuhan yang berada dalam rentang usia 4-5 tahun menjadi subjek dalam penelitian ini.

Dalam pengamatan yang dilakukan selama penelitian berlangsung didapat data bahwa anak usia 4-5 tahun yang tinggal di panti asuhan telah memiliki keterampilan membantu diri sendiri. Keterampilan membantu diri sendiri yang dimiliki anak-anak tersebut muncul dalam pemenuhan kebutuhan dan tugas yang dapat dilakukan tanpa intervensi dari orang dewasa. Data di lapangan menunjukkan bahwa kesempatan melakukan tugas dan pemenuhan kebutuhan diberikan pengasuh. Kesempatan mencoba tersebut dilakukan dalam proses pengembangan keterampilan membantu diri sendiri yang diberikan pengasuh pada Yayasan Arrohmaniyah Panti Asuhan Yatim Piatu Anni'mah.
\end{abstract}

Kata kunci : keterampilan membantu diri sendiri, stimulasi, panti asuhan.

\section{DEVELOPING THE SELF-SKILLS IN THE ORPHANAGE CHILDREN AGED 4-5 YEARS}

\begin{abstract}
This study aims to investigate the case of the self-help skills in the orphanage children aged 4-5 years old. The study took place at Yayasan Arrohmaniyah Panti Asuhan Yatim Piatu Anni'mah, Cakung, East Jakarta. The method used in this research is a case study. Data collection techniques used was observation, interview, and documentation. In the data analysis, this study using Miles and Huberman. Activities undertaken in the analysis of data such as data reduction, data display and conclusion drawing / verification. Orphanage children who are in the age range 4-5 years to be subjects in this study. In the observations made during the study obtained data is that children aged 4-5 years living in orphanages have had self-help skills. Self-help skills possessed these children appear in fulfilling the needs and tasks that can be done without the intervention of an adult. Field data indicate that the opportunity to do the task and given caregiver needs. Attempts are made in the process of growing self-help skills provided caregivers on Yayasan Arrohmaniyah Panti Asuhan Yatim Piatu Anni'mah.
\end{abstract}

Keywords: self-help skill, orphanage children, stimulation

\section{PENDAHULUAN}

Sebagai individu, anak memiliki kebutuhannya masing-masing. Dalam memenuhi kebutuhannya, anak tidak bisa terus menggantungkan hidupnya terhadap pertolongan orang lain. Meskipun dalam usia yang muda, anak diharapkan menjadi individu yang mandiri. Hal inilah yang mendorong dilaksanakannya pengembangan kemandirian pada anak sejak dini. Masih banyak masyarakat yang belum menyadari pentingnya pengembangan kemandirian sejak dini.
Menurut Nakita dan Hilman Hilmansyah masih banyak anak yang selama 24 jam selalu dilayani, baik oleh pengasuhnya maupun orang tuanya sendiri. Hal tersebut menyebabkan kurangnya kesempatan yang didapat anak untuk mencoba memenuhi kebutuhan dasar mereka. Kesempatan yang diberikan kepada anak untuk mencoba memenuhi kebutuhan dasar mereka sendiri akan mendorong terbentuknya kemandirian pada diri anak. Kebiasaan mendapat 
pertolongkan bahkan pelayanan dalam memenuhi kebutuhan dasar anak ini yang membuat anak menjadi tidak mandiri.

Kebutuhan dasar yang dapat anak penuhi secara mandiri meliputi makanan, pakaian, hingga perawatan dan kebersihan diri. Pemenuhan kebutuhan menjadi rutinitas anak setiap hari. Rutinitas pemenuhan kebutuhan dasar ini disebut dengan ADL (Activities of Daily Living). Dalam membantu menyelesaikan rutinitas pemenuhan kebutuhan dasar, anak membutuhkan keterampilan membantu diri sendiri. Keterampilan membantu diri sendiri harus dimiliki setiap individu untuk membantu diri mereka menjadi individu mandiri tidak terkecuali untuk anak usia dini. Pentingnya keterampilan membantu diri sendiri ini yang membuat dibutuhkannya pengembangan keterampilan tersebutk untuk anak sejak dini.

Keterampilan membantu diri sendiri dapat dikembangkan sejak anak berusia dini. Setiap jenjang usia pada anak terdapat kemampuan yang semakin bertambah seiring bertambahnya usia. Anak berusia 4-5 tahun sudah mulai memiliki kemampuan dalam menerapkan keterampilan membantu diri sendiri untuk memenuhi kebutuhan dasar anak. Four to five year olds can go to the toilet by themselves, use toilet paper properly and flush the toilet (Goverment of Western Australia). Anak usia 4-5 tahun dapat pergi dan menggunakan toilet sendiri. Setiap tahunnya, kemampuan anak semakin berkembang. Kemampuan anak yang terus berkembang akan berjalan seiring dengan keterampilan membantu diri sendiri mereka. Kemampuan anak dalam keterampilan membantu diri sendiri lekat hubungannya dengan peran orang dewasa yang memberikan stimulasi untuk perkembangan anak di lingkungan mereka. Orang dewasa yang terdekat dengan anak adalah orang tua

Orang tua memiliki peran pada tumbuh dan kembang anak. Peran orang tua ini pun dibutuhkan dalam pengembangan kemampuan anak tidak terkecuali untuk keterampilan membantu diri sendiri anak. Pada kenyataannya, tidak semua anak terlahir dan dibesarkan dengan keberadaan orang tua di sisi mereka. Menurut Resti (2013), Badan Pusat Statistik (BPS) menyatakan bahwa 2,15 juta anak dengan usia kurang dari 5 tahun diantaranya tidak hidup dengan orang tua. Data tersebut menunjukkan bahwa tidak semua anak merasakan peran orang tua dalam hidup mereka. Ketidakhadiran orang tua dalam hidup anak tidak membuat kebutuhan anak akan pendidikan yang diberikan orang dewasa di lingkungan terdekat anak menjadi hilang. Anak tetap membutuhkan orang dewasa untuk mengembangkan seluruh kemampuan mereka. Peran orang tua dapat digantikan oleh orang dewasa terdekat lainnya di lingkungan anak.

Orang dewasa terdekat yang berada di lingkungan anak dapat menggantikan peran orang tua. Orang dewasa terdekat dapat ditemui anak di lembaga atau yayasan. Salah satu lembaga atau yayasan yang memiliki pekerja sosial atau pengasuh (care giver) sebagai pengganti orang tua bagi anak asuh yaitu Panti Sosial Asuhan Anak (PSAA). Keberadaan PSAA menjadi salah satu solusi bagi masalah pendidikan dan pengasuhan anak tanpa dampingan orang tua. PSAA menjadi salah satu alternatif tempat dimana anak yang tidak memiliki orang tua kandung mendapatkan pengasuhan dan pendidikan serta merasakan keberadaan sebuah keluarga.

Berdasarkan uraian di atas peneliti tertarik untuk mengadakan penelitian yang berkaitan dengan keterampilan membantu diri sendiri di panti sosial. Penelitian ini akan menggali cara pengembangan keterampilan membantu diri sendiri anak-anak tanpa orang tua usia 4-5 tahun di lingkungan PSAA. Tujuan penelitian adalah untuk menggali dan mendeskripsikan karakteristik keterampilan membantu diri sendiri anak tanpa orang tua usia 4-5 tahun. Selain itu, penelitian ini bertujuan untuk mendapatkan informasi mendalam terkait proses pengembangan dan peran PSAA dalam keterampilan membantu diri sendiri pada anak tanpa orang tua usia 4-5 tahun. Penelitian ini dilakukan dalam lingkungan Yayasan Panti Asuhan Yatim Piatu Anni'mah, Cakung, Jakarta Timur.

\section{Keterampilan Membantu Diri Sendiri}

Keterampilan membantu diri sendiri yang dimiliki anak akan membantu dalam menjalani hidup secara mandiri. Dalam Training Module Self-Help (2013), Skill Self-help skills can be defined as those basic skills needed to take care of one's own needs. Keterampilan membantu diri sendiri dapat dinyatakan sebagai keterampilan dasar yang dibutuhkan untuk memenuhi kebutuhan seseorang. Setiap manusia memiliki kebutuhan dasar yang harus dipenuhi. Pemenuhan kebutuhan dasar tersebut tidak dapat secara terus menerus digantungkan atas pertolongan orang lain.

Pendapat mengenai keterampilan membantu diri sendiri pun dikemukakan oleh Reinhart. Reinhart (2006) mengemukakan self-help skill are those skills that help child gain control over his/her body over time. Those skills include performing simple two and three step tasks, taking care of personal bathroom needs, cleaning up after snack and play, dreesing oneself with limited help from adults. Pendapat yang dikemukakan oleh Reinhart menjelaskan bahwa keterampilan membantu diri sendiri merupakan 
beberapa keterampilan yang membantu anak mencapai kontrol akan tubuh. Ketika anak mencapai kontrol akan tubuhnya maka anak secara utuh bertanggung jawab akan dirinya termasuk untuk memenuhi kebutuhan dasar mereka sendiri. Hal ini terlihat ketika anak merasa lapar. Ketika lapar maka anak yang telah mencapai kontrol akan tubuh akan mengontrol dirinya untuk memenuhi kebutuhan dasar anak tersebut dengan mengambil makanan dan menyuapinya ke dalam mulut secara mandiri.

Keterampilan membantu diri sendiri memberikan manfaat pada pribadi anak. Conger dan Rose (1995) pun mengemukakan pendapatnya. (1) builds a good self-concept and self-esteem (that is, self-value), (2) helps children respect other people and accept individual responsibility; helps them become part of a team effort (respecting others and accepting responsibility), (3) give children experiences in decision-making and problems-solving (coping skill), and (4) give children more effective time with caregivers, who are freed from routines and have more time to interact with the children. Manfaat yang diberikan dari hadirnya keterampilan membantu diri sendiri tidak hanya terlihat saat anak masih masa usia dini. Keterampilan membantu diri sendiri akan membentuk anak menjadi orang dewasa dengan konsep diri dan kepercayaan diri yang baik karena telah dapat hidup tanpa ketergantungan akan pertolongan orang lain. Berkembangnya keterampilan membantu diri sendiri pun memberikan anak rasa menghargai akan tanggung jawab setiap individu. Perkembangan keterampilan membantu diri sendiri pada anak akan berbanding lurus dengan pengalaman yang dimilikinya dalam membuat keputusan dan menyelesaikan masalah. Hal tersebut menunjukkan bahwa perkembangan keterampilan membantu diri sendiri akan bermanfaat bagi anak untuk tumbuh dan berkembang menjadi manusia dewasa kelak.Manfaat dari keberadaan keterampilan membantu diri sendiri akan terasa hingga anak tumbuh dewasa.

Pengembangan keterampilan membantu diri sendiri meliputi beberapa hal yang dapat dilakukan lingkungan untuk menstimulasi anak. Disebutkan oleh Conger dan Rose mengenai pengembangan keterampilan membantu diri sendiri terdapat beberapa hal yang dapat dilakukan, antara lain (1) giving them many opportunities and encouragement to do things for themselves and others, (2) praising them for their efforts to care for themselves, even their attempts are not entirely successful, (3) accepting their interest in trying new tasks and skills, and giving support only when needed, (4) allowing enough time for them to do things for themselves, without having the pressure of having to hurry, (5) encouraging them to ask for assistance if they need it, and avoiding taking over from children if they are slow or experiencing difficulty with a tasks, (6) breaking new and more complex tasks down into smaller steps that can either be explained or demonstrated to children. Orang dewasa di lingkungan anak memegang peran untuk mengembangkan keterampilan membantu diri sendiri pada diri anak.

Peran orang dewasa dalam mengembangkan keterampilan membantu diri sendiri. Terdapat halhal yang harus diperhatikan dalam pengembangan keterampilan membantu diri sendiri yag terkait dengan kesempatan mencoba, pujian, perbedaan ketertarikan, jangka waktu, dorongan, dan intruksi yang diberikan. Pemberian kesempatan dan dorongan kepada anak untuk mencoba memenuhi kebutuhan dasar mereka sendiri menjadi hal penting dalam pengembangan keterampilan membantu diri sendiri. Dalam mengembangkan keterampilan membantu diri sendiri pun dibutuhkan pujian agar anak terdorong untuk terus mencoba memenuhi kebutuhan dasarnya secara mandiri.

Selain itu, setiap anak memiliki ketertarikan yang berbeda terhadap setiap rutinitas pemenuhan kebutuhan dasar, orang dewasa sebaiknya memahami ketertarikan anak dan membantu mereka bila memang dibutuhkan. Waktu yang dibutuhkan anak untuk menyelesaikan rutinitas mereka berbeda dengan orang dewasa. Anak membutuhkan waktu yang lebih panjang untuk memenuhi kebutuhan dasar mereka. Orang dewasa sebaiknya memaklumi dan memberika waktu yang cukup kepada anak dalam memenuhi kebutuhan dasar mereka sendiri. Orang dewasa pun sebaiknya mendorong anak untuk tetap meminta bantuan bila mengalami kesulitan. Kesiagaan orang dewasa selama anak belajar memenuhi kebutuhan dasarnya secara mandiri sangat dibutuhkan. Instruksi yang diberikan kepada anak pun sebaiknya berupa langkah-langkah yang sederhana.

Anak memiliki tugas perkembangan pada setiap masa usianya. Tugas perkembangan yang dimiliki setiap anak berbeda sesuai dengan usianya. Menu Pembelajaran Generik Anak Usia Dini tahun 2009 menyebutkan bahwa anak usia 4-5 tahun dapat memegang garpu dengan jari-jari, dapat mengunakan pisau untuk mengoles, dapat melepas pakaian yang harus ditarik ke atas, dapat berpakaian sendiri tanpa diawasi kecuali untuk mengencangkan, dapat membuka ritseleting, dapat mengenakan ikat pinggang, dapat menalikan tali sepatu, hingga dapat berusaha untuk membuat pita tali sepatu. Hal ini pun 
dikuatkan oleh beberapa pendapat dari pemerintahan negara lain.

Beberapa pakar pun mengemukakan pandangan mengenai perkembangan pada anak usia 4-5 tahun. National Association for the Education of Young Children (NAECY) (2002) menyebutkan karakteristik keterampilan membantu diri sendiri pada anak usia 4 tahun. Dresses and undresses without assistance; brushes teeth and combs hair; spills rarely with cup or spoon; laces shoes or clothing but cannot yet tie. Seorang anak menginjak usia 4 tahun menurut NAECY sudah mampu memakai dan melepas pakaian tanpa bantuan, menyikat gigi dan menyisir rambut, menggunakan cangkir atau sendok, memakai sepatu tetapi belum dapat mengikat talinya. Pada usia 4-5 tahun, keterampilan membantu diri sendiri yang dimiliki anak berkisar kepada tugas-tugas sederhana. Tugas tersebut akan semakin anak kuasai seiring pertumbuhan dan perkembangan anak serta pengalaman yang anak dapatkan. Selain itu, aktivitas keseharian pun akan semakin bertambah seiring dengan kemampuan yang dimiliki anak pada masa usia selanjutnya.

\section{Panti Sosial Asuhan Anak (PSAA)}

Setiap anak-anak memiliki kebutuhan yang paling dasar yaitu kebutuhan untuk bertumbuh dan berkembang bersama keluarga. Kebutuhan paling dasar tersebut yang harus terpenuhi tidak terkecuali untuk anak-anak yatim piatu. PSAA sebagai wadah untuk anak-anak yatim piatu mendapatkan pemenuhan kebutuhan tersebut. Dalam Departemen Sosial Republik Indonesia (2004) PSAA adalah suatu lembaga pelayanan profesional yang bertanggung jawab memberikan pengasuhan dan pelayanan fungsi orang tua kepada anak terlantar. PSAA melaksanakan penyantunan dan pengentasan anak terlantar, memberikan pelayanan pengganti orang tua/wali dalam memenuhi kebutuhan fisik, mental, dan sosial anak. PSAA menjadi salah satu solusi bagi anakanak tanpa orang tua untuk merasakan hidup dengan keluarga walaupun bukan keluarga kandung.

Terdapat pendapat pun dikemukakan terkait keberadaan PSAA. Gospor Nabor menjelaskan bahwa PSAA adalah suatu lembaga pelayanan sosial yang didirikan oleh pemerintah maupun masyarakat yang bertujuan untuk membantu atau memberikan bantuan terhadap individu, kelompok masyarakat dalam upaya memenuhi kebutuhan hidup (Erwintri, 2013). Dikemukakan bahwa PSAA sebagai lembaga sosial yang didirikan secara sengaja oleh pemerintah ataupun masyarakat. Keberadaan PSAA dapat membantu individu atau kelompok dalam memenuhi kebutuhan hidup sebagai wujud upaya terjaminnya kesejahteraan sosial. Keberadaan PSAA pun diatur oleh pemerintah di setiap Negara.

Departemen Sosial Republik Indonesia mengatur operasional PSAA. Departemen Sosial juga mengemukakan tujuan atas didirikannya PSAA. Tujuan dari PSAA antara lain: (1) Terwujud hak atau kebutuhan anak yaitu kelangsungan hidup, tumbuh kembang, perlindungan dan partisipasi. (2) terwujudnya pelayanan atas dasar standar professional yaitu dikelola oleh tenaga pelaksana yang memenuhi standar profesi, terlaksananya manajemen kasus sebagai pendekatan pelayanan yang memungkinkan anak memperoleh pemenuhan kebutuhan yang berasal dari keanekaragaman sumber, meningkatnya kualitas kehidupan seharihari di lingkungan panti yang memungkinkan anak berintegrasi dengan masyarakat secara serasi dan harmonis, meningkatnya kepedulian masyarakat sebagai relawan sosial. (3) terwujudnya jaringan kerja dan sistem informasi pelayan kesejahteraan anak secara berkelanjutan baik horizontal maupun vertikal.

Pemerintah Indonesia memiliki departemen yang mengatur keberadaan PSAA. Tujuan didirikannya PSAA yang diatur orang Departemen Sosial Republik Indonesia ini berpusat pada anak. Selain tujuan didirikannya PSAA, Depatemen Sosial Republik Indonesia pun memiliki pendapat mengenai sasaran dari PSAA.

Sasaran dari PSAA pun diatur oleh Departemen Sosial. Terdapat pembagian sasaran terhadap masyarakat yang mendapatkan pelayanan PSAA di negara Indonesia.

Sasaran utama adalah anak terlantar yang mencakup yatim terlantar, piatu terlantar atau yatim piatu terlantar dengtan usia dibawah 18 tahun dan belum menikah, anak yang keluarganya dalam waktu relatif lama tidak mampu melaksanakan fungsinya secara wajar, dan anak yang keluarganya mengalami perpecahan, mengidap penyakit kronis, terpidana, korban bencana, dan lain-lain. Sasaran sekunder yaitu semua anak di lingkungan masyarakat yang memenuhi persyaratan untuk memperoleh pelayanan di lingkungan PSAA. Anak-anak tersebut adalah anak yang disebut sebagai 'klien potensial' yang kini berada di lingkungan masyarakat. Sasaran tersier yaitu semua pihak yang berkemampuan sebagai sistem sumber antara lain pemerintah daerah, organisasi sosial/ LSM, perguruan tinggi, dunia usaha, media massa, organisasi profesi, pemuka masyarakat dan agama, relawan sosial, serta warga masyarakat peduli.

Pengaturan sasaran dari PSAA yang 
dikemukakan oleh Departemen Sosial Republik Indonesia ini ditujukan agar keberadaan PSAA menjadi tepat sasaran. Setiap anak berhak untuk mendapatkan lingkungan layak. Banyak anak-anak tunawisma yang menghabiskan tahun-tahun awal krusialnya dalam lingkungan yang tidak stabil, tidak aman, dan sering kali tidak bersih. Setiap anak membutuhkan tempat berteduh dan bergantung, PSAA memberikannya kepada anak-anak tersebut.

\section{METODE PENELITIAN}

Dalam penelitian ini, metode yang digunakan dalam penelitian ini adalah metode kualitatif. Dalam penelitian ini, peneliti menggunakan studi kasus sebagai jenis penelitian dengan metode kualitatif. Penelitian ini dilaksanakan di Panti Asuhan Yatim Piatu Anni'mah. Yayasan ini berlokasi di Jalan Hasan No.27 Penggilingan, Cakung, Jakarta Timur. Penelitian akan berlangsung selama bulan Mei 2013

Pada penelitian ini, snowball sampling technique digunakan untuk menentukan subjek penelitian. Pemilihan sumber data didasari kebutuhan peneliti. Sumber data pada penelitian ini adalah anak, pengasuh, dan pemilik yayasan. Penelitian ini akan mengunakan beberapa teknik yang digunakan untuk mengumpulkankan dan merekam data. Teknik tersebut adalah observasi, wawancara, dan dokumentasi.

Penelitian ini mengikuti pendapat Miles dan Huberman dalam menganalisis data. Miles dan Huberman menyebutkan terdapat tiga aktivitas yang dilakukan dalam analisis data. Aktivitas yang dilakukan dalam analisis data yaitu data reduction, data display, dan conclusion drawing/verification. Dalam melihat keabsahan data, teknik yang digunakan adalah perpanjangan pengamatan dan triangulasi.

\section{HASIL DAN PEMBAHASAN}

Berdasarkan hasil penelitian yang dilakukan peneliti melalui pengamatan, wawancara, dan dokumentasi diperoleh beberapa data. Data tersebut mengenai kegiatan dan proses pengembangan dalam keterampilan membantu diri sendiri pada anak asuh di Yayasan Arrohmaniyah Panti Asuhan Yatim Piatu Anni'mah. Dalam penelitian yang berlangsung tampak pola yang terkait pada proses pengembangan keterampilan membantu diri sendiri. Pola-pola pengembangan keterampilan membantu diri sendiri tersebut antara lain (1) pola pengembangan dengan intervensi yang diberikan pengasuh kepada anak, (2) pola pengembangan dengan adanya bantuan yang inkonsistensi, (3) pola pengembangan dengan menggunakan instruksi.

1. Pola Pengembangan dengan Intervensi yang Diberikan Pengasuh

Pola pertama yang ditemukan dalam proses pengembangan keterampilan membantu diri sendiri yaitu pola pengembangan dengan intervensi yang diberikan pengasuh kepada anak. Kegiatan yang masih terdapat intervensi dalam proses pengembangannya adalah kegiatan makan, mandi, hingga toileting. Bantuan dari pengasuh masih diberikan dalam kegiatan ataupun pemenuhan kebutuhan anak.

Intervensi yang dilakukan pengasuh pada kegiatan makan yaitu dalam hal menyiapkan makanan dan membersihkan peralatan makan. Selain itu, intervensi juga dilakukan ketika anak ingin mandi, pengasuh akan mengambilkan peralatan mandi anak seperti sampo, sabun, sikat gigi, pasta gigi, serta handuk. Ketika selesai mandi pun intervensi dilakukan pengasuh. Pengasuh mengambil peralatan mandi dan baju kotor anak untuk dirapikan. Intervensi lain dilakukan pengasuh saat kegiatan toiletting. Pengasuh membantu anak ketika membersihkan diri saat selesai memenuhi kebutuhan eksresi. Pelaksanaan pengembangan keterampilan menolong diri sendiri dilakukan dengan intervensi dari pengasuh pada beberapa anak.

2. Pola Pengembangan dengan Adanya Bantuan yang Inkonsistensi

Pola lainnya yang ditemukan peneliti yaitu adanya bantuan yang inkonsistensi dalam proses pengembangan keterampilan membantu diri sendiri. Pola ini terkait dengan bantuan yang diberikan pengasuh kepada anak secara tidak rutin. Pemberian bantuan disesuaikan dengan kondisi yang dihadapai anak atau permintaan anak secara langsung. Pola pengembangan dengan adanya bantuan yang inkonsistensi ini ditemukan pada kegiatan makan, berpakaian, serta ketika anak mengeringkan badan sehabis mandi.

Pada kegiatan makan, muncul bantuan inkonsistensi yang diberikan pengasuh kepada anak. Pengasuh menyuapi anak hingga makanan diatas piring habis. Hal tersebut dilakukan karena jangka waktu makan anak yang sudah melewati 
jam makan, namun belum selesai. Bantuan yang secara inkonsistensi dilakukan pengasuh untuk anak terjadi pula saat anak mengeringkan badan setelah mandi. Ketika anak selesai mandi, Pengasuh menghampiri dan mengeringkan badan anak dengan handuk. Hal tersebut dikarenakan anak belum mampu mengeringkan beberapa bagian tubuh yang sulit dijangkau, seperti punggung. Selain itu, bantuan diberikan untuk merapikan handuk dengan menggantung di samping pintu kamar mandi. Hal tersebut dikarenakan posisi rak gantungan yang belum sesuai dengan tinggi badan anak. Bantuan lain yang diberikan secara inkonsistensi oleh pengasuh kepada anak terjadi dalam kegiatan berpakaian. Ketika anak menghampiri dan menyampaikan keinginannya untuk mandi kepada pengasuh, pengasuh segera melepaskan pakaian anak. Selanjutanya ketika anak selesai mandi pengasuh memberikan bantuan dalam berpakaian.
3. Pola Pengembangan dengan Menggunakan Instruksi

Pola yang muncul selanjutnya adalah pola pengembangan keterampilan membantu diri sendiri yang menggunakan instruksi dalam prosesnya. Instruksi ini diberikan saat rutinitas sedang berlangsung. Kegiatan yang menggunakan instruksi dalam prosesnya adalah kegiatan mandi.

Dalam proses kegiatan mandi, pada awal pengamatan ditemukan instruksi yang diberikan pengasuh kepada anak. Instruksi yang diberikan yaitu pengasuh yang menyuruh anak untuk menggunakan sampo, sabun hingga menyikat gigi. Instruksi seperti menghentikan kegiatan mandi pun diberikan pengasuh kepada anak bermain air saat mandi. Berdasarkan hasil wawancara, instruksi diberikan pengasuh sebagai cara mereka mengembangkan keterampilan mandi tanpa bantuan kepada anak.

\section{PENUTUP}

\section{Kesimpulan}

Pentingnya peran orang tua dalam pengembangan keterampilan bantu diri tidak dapat dirasakan oleh semua anak. Penelitian yang akan dilakukan terkait pengembangan keterampilan membantu diri sendiri pada anak-anak usia 4-5 tahun. Anak-anak yang menjadi subjek penelitian berada dalam satu lingkungan yang sama yaitu lingkungan PSAA.

Keterampilan membantu diri sendiri merupakan keterampilan yang digunakan untuk membantu anak dalam memenuhi kebutuhan yang berkaitan dengan kebersihan, perawatan, pakaian, dan mainan miliknya sendiri secara mandiri. Pada usia 4-5 tahun, keterampilan membantu diri sendiri yang dimiliki anak berkisar kepada tugas-tugas sederhana. Aktivitas keseharian yang bisa anak usia 4-5 tahun lakukan sendiri dengan keterampilan membantu diri sendiri antara lain aktivitas yang dilakukan sehubungan dengan mandi, makan, berpakaian, dan toileting.

Cara yang digunakan pengasuh Panti Asuhan Yatim Piatu Anni'mah dalam mengembangkan kemampuan membantu diri sendiri pun bertahap. Bantuan secara penuh pada awal masa pengembangan diberikan. Pengurangan bantuan akan dilakukan seiring berjalannya waktu. Bantuan berupa instruksi baik untuk mengingat ataupun perintah diberikan pengasuh ketika anak memenuhi kebutuhan mereka sendiri. Kesempatan untuk menyelesaikan tugas tanpa bantuan pun diberikan pengasuh kepada anak.

Hambatan dalam melakukan tugas sendiri ditemui oleh anak. Hambatan terjadi karena peletakkan alat-alat yang mereka butuhkan tidak dapat mere jangkau sehingga bantuan dibutuhkan. Hal inilah yang menyebabkan bantuan seringkali mereka dapatkan walau tanpa permintaan. Alasan demi keamanan, keefektifias waktu dikemukakan oleh para pengasuh atas bantuan yang diberikan.

\section{DAFTAR PUSTAKA}

Conger, F.S. \& Rose, I.B., (1995). Child care aide skill. Australia: McPherson's Printing Group.

Departemen Sosial Republik Indonesia, (2004). Acuan umum pelayanan sosial di PSAA. Departemen Sosial Republik Indonesia

Ewintri, (2012). Pengertian panti sosial asuhan anak Diakses tanggal 03 Maret 2013 melalui http:// ewintri bengkulu.blogspot.com/2012/10/penger- tian-panti-sosial-asuhan-anak.html

Goverment of Western Australia. Child development 4-5 years old. Australia: Departement of Health

Menu Pembelajaran Generik Anak Usia Dini Revisi (2009).

Nakita \& Hilmansyah, H. (2011). Tiga penyebab balita kurang mandiri. Diakses tanggal 23 Januari 2013 melalui http://female.kompas. 
com/read/2011/09/28/11414157/3.PenyebabBalitaKurangMandiri

National Association for the Education of Young Children, (2002). Developmentally appropriate practice in early childhood education. Washington D.C,

Putting Children First (the magazine of the National Childcare Accreditation Council, NCAC), (2009), Supporting children's development. Australian Goverment,

Reinhart, A. (2006). Self-help skill. University od Illinois Extension,
Resti, P. (2010). Waduh mayoritas anak di panti asuhan punya orangtua. Diakses tanggal 01 Februari 2013 melaluihttp://www.republika.co.id/ berita/breakingnews/nasional/10/12/16/152513waduh-mayoritas-anak-di-panti-asuhan-punya-orang-tua

Stephens, K. Self help skills and chores build children's identity and confidence (Parenting exchange).

Training module self-help skill. Diakses 18 Maret 2013 melalui https://docs.google.com/viewer? $a=v \& q=$ cache:jI3elcHsIDIJ:www.highreach. com/highreach_cms/LinkClick. 